БЕГИЧЕВА ОЛЬга ВикТоровна

кандидат искусствоведения,

профессор кафедры истории и теории музыки Волгоградского государственного института искусств и культуры,

Волгоград, Россиская Федерация Olga V. BEGICHEVA

Cand. Sci. (Art Criticism), Prof., Volgograd State Institute of Arts and Culture, Volgograd, Russian Federation, olilog@yandex.ru

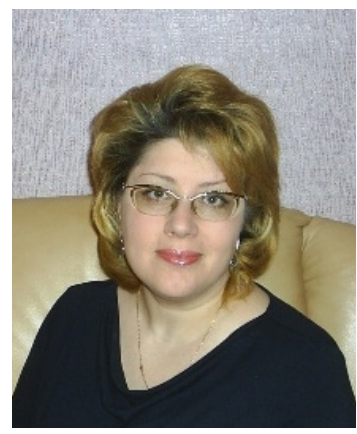

\section{«0бертоны» романтической баллады в творчестве современных композиторов Кубани (на примере произведений Константина Пашкова)}

\section{The "Overtones" of the Romantic Ballad in the Works of Modern Composers of Kuban (On the Example of Works by Konstantin Pashkov)}

В статье рассматривается трансформация жанра романтической баллады в творчестве современного краснодарского композитора К. Пашкова. Во главу угла ставится когнитивный подход к жанру, который позволяет приблизиться к его архетипу, а затем проследить возможные пути деканонизации сложившейся жанровой формы. Опираясь на методы историко-культурологического, музыковедческого, а также сравнительного анализа делается вывод о трансляции жанровой модели романтической баллады за пределами XIX столетия. Введение в научный обиход цикла Пять пьес для струнного оркестра направлено на популяризацию творчества молодого талантливого композитора Кубани.

Ключевые слова: композиторы Кубани, Константин Пашков, романтическая баллада, трансформация жанра, балладность.

Становление, стабилизация, дестабилизация - последовательные стадии развития жанра, рассматриваемые с позиций нормативной поэтики. За ними стоит движение к канону, кристаллизация жанровых форм и устойчивое продолжительное господство некоей нормы, задающей конвенциональные соглашения между автором и реципиентом. В том же случае, когда произведение попадает на «территорию» ненормативной поэтики, указанные выше стадии жанровой эволюции приобретают специфические очертания. Границы между каноном и его разрушением становятся расплывчатыми, жанр предстает 
как динамично развивающаяся система, существующая одновременно и в становлении, и в изменении.

Эти тонкие наблюдения, неоднократно высказываемые филологами, до настоящего времени не нашли своего применения в музыкознании, тем не менее именно динамическая концепция жанра, активно разрабатываемая в работах С.Н.Бройтмана [2], О.В.Зырянова [3], видится наиболее перспективной в свете когнитивного подхода к жанру, обозначившегося в современных междисциплинарных исследованиях музыковедов [1].

Ярким образцом, демонстрирующим данный тезис, является романтическая баллада. Для научной рефлексии работа с таким материалом представляет определенную сложность. Теория балладного жанра эпохи романтизма на сегодняшний день «пробуксовывает» неслучайно - ведь живой исторический процесс, за которым стоят реальные персоналии и художественные образцы, выплескивает на поверхность сочинения, кардинально расходящиеся между собой в образном содержании, в стилистике и средствах художественной выразительности.

Что нам сегодня достоверно известно об этом жанре?

Во-первых, то, что его путь в художественную культуру романтизма пролегал через многовековую фольклорную традицию. Во-вторых, что он одновременно утвердился и в литературе, и музыке, сопровождающей поэтические опусы, а затем получил музыкальную автономию, не потеряв с литературой глубинной связи благодаря повествовательному дискурсу и фабулярности. В-третьих, нам известны его эмоционально-содержательные доминанты, выраженные через драматический пафос высказывания с присутствием фантастического элемента в виде фольклорного пласта всевозможной «нежити». Установлено, что взаимодействие двух миров («здешнего» и «потустороннего») жанрообразующий компонент баллады [5].

Приведенная статическая концепция жанра романтической баллады применительно к реалиям художественной практики, особенно за пределами романтизма, не способна «высветить» балладное начало (модус балладности) в сочинениях иной жанровой номинации, построенных по принципам балладной поэтики. Выход из сложившегося положения нам видится в динамическом подходе к теории жанра, когда последний, говоря словами О.А.Проскурина, рассматривается не как «объект воздействия», а как «субъект развития» [4, с. 71]. В этом случае, обращаясь к романтической балладе как к жанровому феномену, сложившемуся в неканонический период и распространившему сферу своего влияния далеко за пределы романтизма, требуется смена исследовательской парадигмы.

В соответствии с последними разработками музыкознания в случае с явлениями, попадающими в эпоху «рефлективного антитрадиционализма» (С.С.Аверинцев), наиболее востребованными являются методы когнитивной поэтики, когда постижение природы балладообразующих признаков осуществляется через жанровые концепты, действующие в междисциплинарном поле гуманитарного знания.

Такой подход позволяет выйти к жанровым универсалиям, извлечь из глубин жанрового архетипа признаки баллады и реконструировать ее в различных историко-стилевых контекстах.

Цель настоящей статьи - рассмотреть проявление балладности на новом витке историко-культурного развития, в творчестве композиторов XXI века. Для реконструкции жанрового архетипа баллады напомним его «опорные точки», выполняющие представительствующие функции в художественной культуре. Это «генеральная интонация» жанра - страх и страдание, возникающая при вторжении мира мертвых в мир живых. Она реализует сюжетные мотивы любви-в-смерти и судьбы. Присутствие мира инобытия всегда предполагает наличие инфернально-фантастического элемента и трагической развязки. Обязательными персонажами баллады являются иномирный пришелец, его возлюбленная и повествователь.

В музыкальных балладах герои маркируются подобающей их жанровому «статусу» лексикой и подчиняются композиционно-драматургической расстановке сил, соответствующей шести сюжетным функциям: нарушение 
ритуального табу - вторжение иномирного пришельца - встреча двух миров - взаимодействие миров - возвращение пришельца - «свадьба-похороны».

В качестве яркого примера, иллюстрирующего пролонгирующие тенденции романтической, баллады нами выбрано творчество современного краснодарского композитора Константина Пашкова. Особый интерес с точки зрения конфигурации жанровых признаков баллады в контексте современной культуры представляет его цикл Пять пьес для струнного оркестра. Каждый номер цикла имеет программный или жанровый заголовок: № 1 «Бал Воланда», № 2 Остинато, № 3 Элегия, № 4 «Trioline», № 5 «Пролетая мимо Ирландии».

«Говорящие» названия первой и последней пьес цикла отсылают слушателя к устойчивым образам-символам романтической культуры, где бал у сатаны был связан с мифологемой шабаша Вальпургиевой ночью и полетом нечисти. Что же касается трех других пьес - Остинато, Элегии и «Trioline»,- то «разговор со слушателем» идет в парадигме полижанровости, получившей наибольшее распространение в творчестве композиторов-романтиков и предполагающий невербальную ассоциативность через отраженный жанр.

Балладная образность и тематика сразу утверждаются в первой пьесе цикла. «Бал Воланда» пестрит аллюзиями на самые популярные баллады романтической культуры. Среди них на первом месте находится «Пляска смерти» К. Сен-Санса. Из «копилки» романтической баллады К. Пашковым удачно извлечены лексемы вальса - томного и одновременно призрачного (пример 1), а также интонация тритона, используемая французским романтиком в качестве «портретного знака» Смерти (nрuмер 2). Тотальная диссонантность, господствующая в современном сочинении, возникает благодаря лейтинтервалу большой септимы, мелькающим отрезкам хроматической гаммы, а разнообразие приемов скрипичной игры pizzicato, glissando, divisi - направлено на создание фантастической атмосферы ирреального бала.

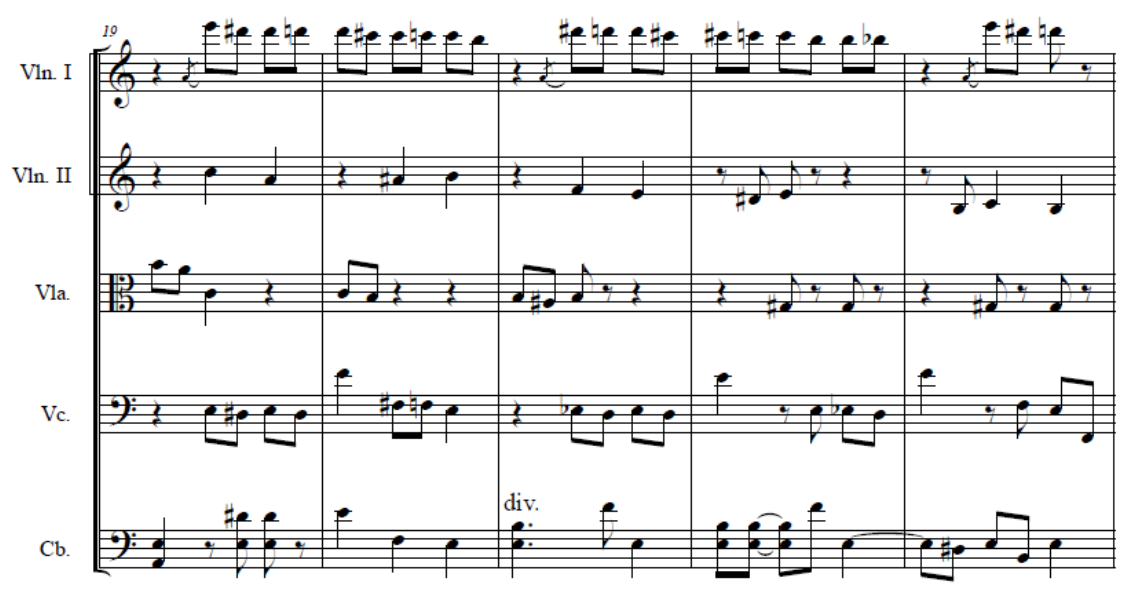

1. К. Пашков. «Бал Воланда». Средний раздел. Тема вальса.

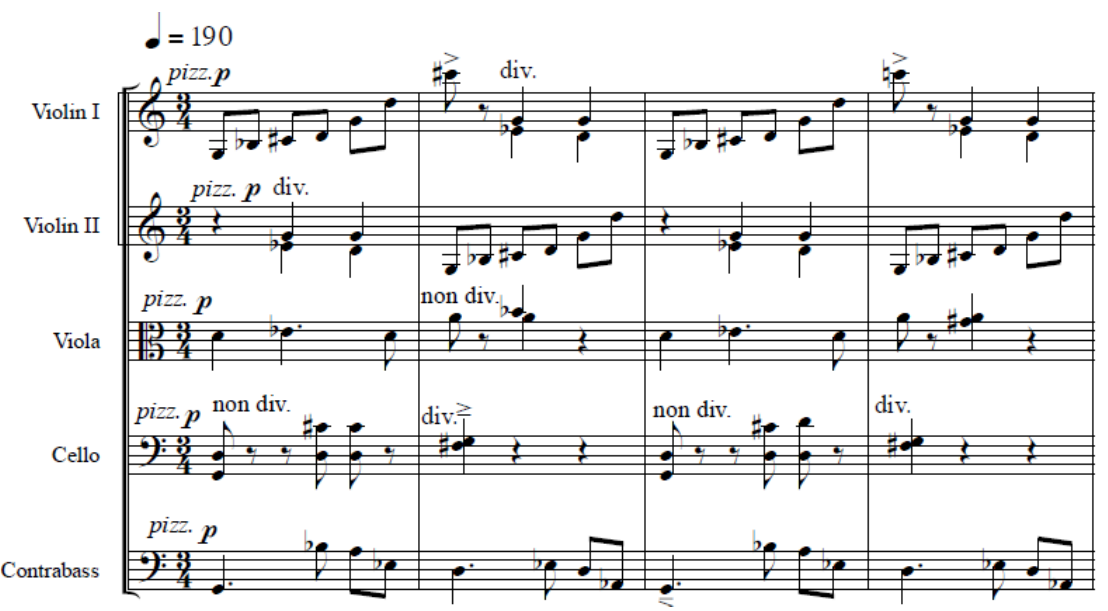

2. К. Пашков. «Бал Воланда». Основной раздел. Тема скерцо 
Элегия, пронизанная скорбными интонациями прощания, становится единственным «островком жизни». Помещенная в центр цикла, она словно зажата в тиски двух механистически-урбанизированных пьес. При этом самой яркой приметой наступательной силы «мертвой материи» становится их тотальная остинатность. Во второй пьесе она выходит на уровень заголовочного комплекса, в четвертой - спрятана внутри остинатной ритмоинтонации триолей. Знаменательно, что одинаково экспрессивно заканчиваются обе пьесы, их финальные возгласы демонстрируют крайнюю сте-

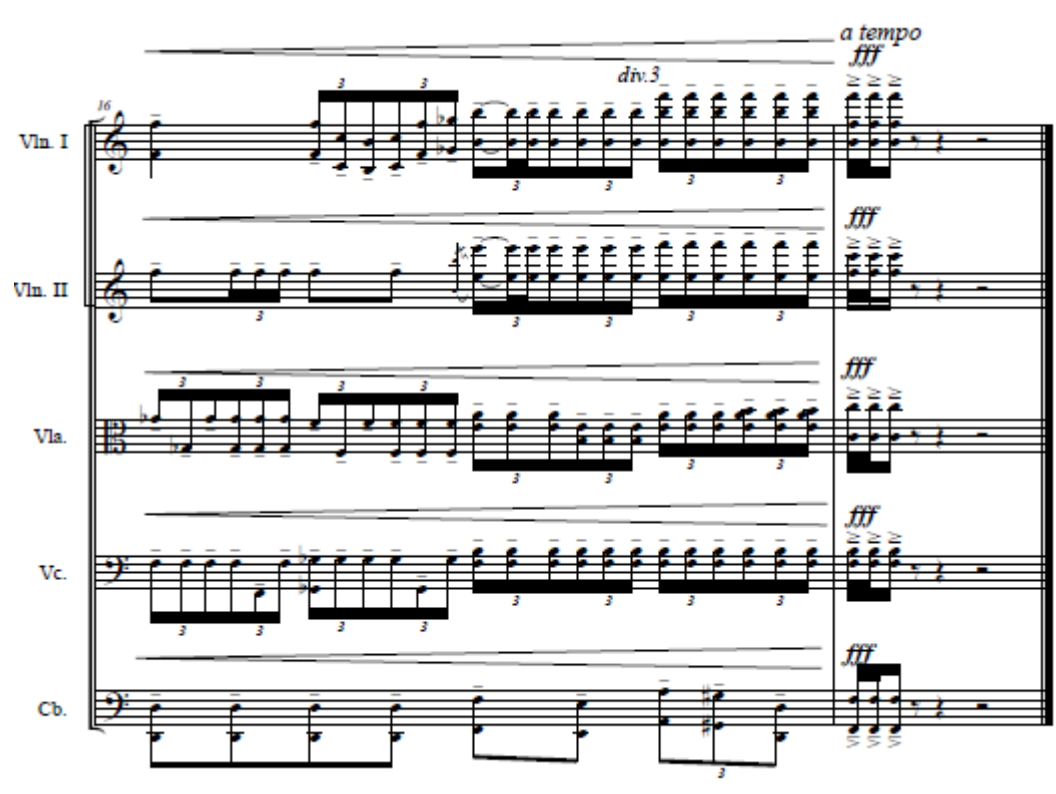

3. К. Пашков. Остинато пень эмоционального напряжения, за которым угадываются ужас, крик отчаяния, возникающие при столкновении с иррациональным миром (примеры 3, 4).

Согласно композиционно-драматургическому архетипу баллады, такое расположение пьес соответствует трем функциям: «вторжению иномирного пришельца» (Остинато), «встрече двух миров» (Элегия) и «возвращению пришельца» («Trioline»), которые, безусловно, корректируются тем, что в роли иномирного пришельца - персонажа фольклорных баллад - выступает внеличная, неперсонифицированная, сила. Однако ее раз-

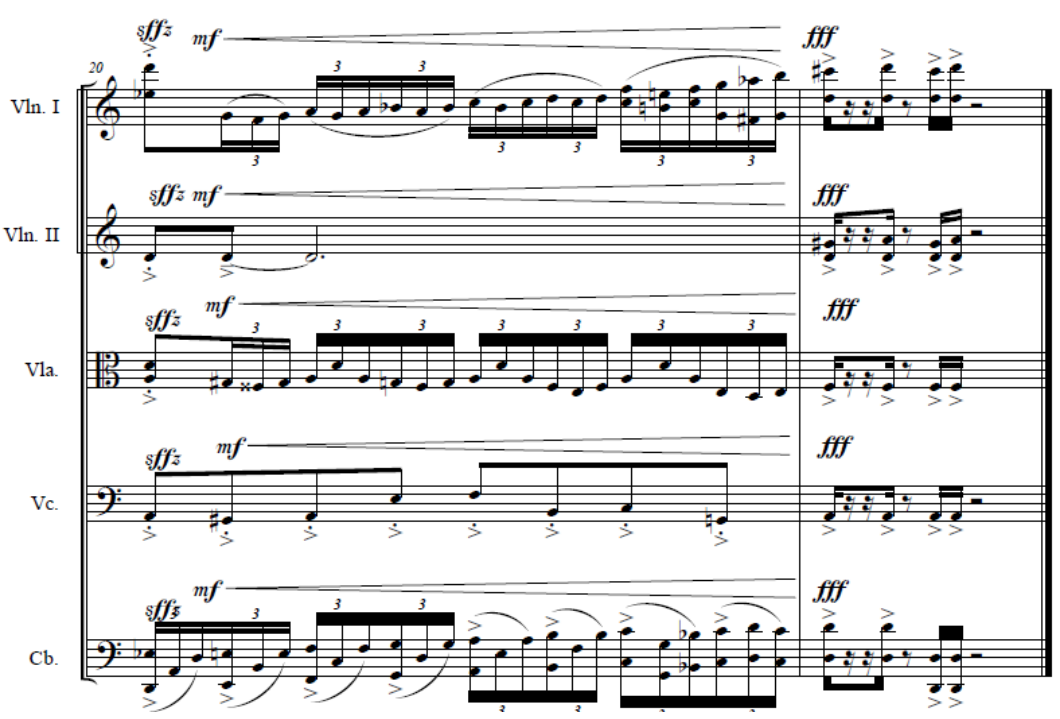

4. К. Пашков. «Trioline» рушительная сущность, типичная для романтической баллады, сохраняет свои функции. Неслучайно композитором для лирического образа избран жанр элегии, генетически связанный с похоронной традицией.

В контексте всего цикла завершающий номер «Пролетая мимо Ирландии» воспринимается как финальный аккорд разлетающейся нечисти. Общеизвестно, что для ирландской мифологии общим местом было представление о колдовстве. Из-за веры Европы в злых духов, которые будто бы населяли Ирландию, эта страна долгое время представлялась зловещим местом. Считалось, что дьявол находит пристанище в таких диких уголках мира, как Лапландия, Финляндия, Ирландия. Неудивительно, что мифическое представление о северном колдовстве, пик которого пришелся на восемнадцатый век, доминировало и в романтических литературных произведениях, начиная с шекспировских ведьм в «Макбете», тени рыбака Питера Э. Баннермана в «Рыбаке Лапландии» и др.

Словом, романтическое воображение всегда подпитывалось дикими легендами, на которые, как нам кажется, есть 
отсылка в последней пьесе. И для реципиента уже не столь важно, что здесь первичное ассоциативный ряд, связанный с романом М. Булгакова, или арка, перекинутая композитором к тексту романтической культуры (ведь Ирландия и ее звуковая атмосфера, воссозданная в пятой пьесе, куда глубже уровня единичного романа, пусть и, без сомнения, гениального).

Таким образом, мы имеем все основания утверждать, что контуры балладного жанра в цикле Пять пьес для струнного оркестра К. Пашкова опознаются на уровне ряда «опорных жанровых точек». Во-первых, в глубинах подтекстового слоя скрыт сюжет табуированной баллады, известный как бал нечисти, или Вальпургиева ночь. Во-вторых, сквозь него всплывают типичные балладные мотивы любви-в-смерти и судьбы. В-третьих, на ин- тонационно-музыкальном уровне «считываются» главные балладные персонажи (представители мира здешнего и потустороннего) - прекрасная возлюбленная и внеличная демоническая сила. Наконец, в композиционно-драматургической организации цикла есть признаки повествовательной балладной формы: пролог, событийный ряд, заключенный в триптихе, и эпилог.

Все вышеизложенное свидетельствует о том, что жанр романтической баллады вторично разыгрывается в творчестве современных композиторов. Жанровый канон, погруженный в глубины авторского слоя произведения, превращается в «образ жанра» (термин О.В. Зырянова), в нем «просвечивает» архетипический балладный сюжет, восстановить который оказывается возможным в парадигме когнитивной поэтики.

\section{Olga V. BEGICHEVA \\ The "Overtones" of the Romantic Ballad in the Works of Modern Composers of Kuban (On the Ex- ample of Works by Konstantin Pashkov)}

Abstract. The sociocultural existence of the genre outside its era is a problem that will never lose its relevance. In fact, the secondary use of the genre in various cultural texts is nothing more than an indicator of the viability of the morphological system of art. In the article, considering the transformation of the romantic ballad in modern culture, the author reveals the genre canon of the ballad, hidden in the depths of the author's layer of the work and turned into an "image of the genre". To reconstruct the genre archetype of the ballad, its "reference points" are distinguished, which perform representative functions in the artistic culture. These include: the "general intonation» of the genre-fear and suffering-arising from the invasion of the world of the dead into the world of the living; plot motifs of love-in-death and fate; the presence of two worlds - "here" and "beyond", which suggests a tragic outcome; the "character frame», consisting of a foreign alien, his beloved and a narrator; compositional and dramatic balance of power corresponding to six plot functions (violation of the ritual taboo - invasion of a foreign alien - meeting of two worlds - interaction of the worlds - return of the alien - "wedding-funeral"). The author chose the cycle Five Pieces for a String Orchestra, the work of the modern Krasnodar composer Konstantin Pashkov, as a vivid example illustrating the prolonging tendencies of the romantic ballad. Each piece of the cycle has a programmatic or genre title: No. 1 "Voland's Ball", No. 2 Ostinato, No. 3 Elegy, No. 4 "Trioline", No. 5 "Flying past Ireland". The self-explanatory names of plays 1 and 5 of the cycle send the listener to steady images, symbols of a romantic culture, in which the ball at the Satan's was associated with the mythology of the Sabbath. As for the other three plays (Ostinato, Elegy and Trioline), their arrangement corresponds to three functions: "invasion of a foreign alien" (Ostinato), "meeting of two worlds" (Elegy) and "return of the alien" ("Trioline"). In the context of the whole cycle, the final piece, "Flying past Ireland", is perceived as the final chord of evil spirits flying away. Thus, there is every reason to assert that the contours of the ballad genre in the Five Pieces for a String Orchestra by Pashkov are recognised at the level of a number of "reference genre points". Firstly, in the depths of the subtext layer, the plot of the taboo ballad is hidden. Secondly, typical ballad motifs show 
through it. Thirdly, at the intonational-musical level, the main ballad characters are "read". Finally, the compositional and dramatic organisation of the cycle has signs of a narrative ballad form: a prologue, a series of events enclosed in a triptych, and an epilogue. All of the above indicates that the genre of the romantic ballad is played out again in the works of modern composers. It was possible to identify the configuration of the genre signs of the ballad in the context of modern culture in the paradigm of cognitive poetics by restoring the archetypal ballad plot.

Keywords: composers of Kuban, Konstantin Pashkov, romantic ballad, transformation of genre, ballad modus.

\section{Использованная литература:}

1. Амрахова А. А. Отечественная теория жанра в свете современных гуманитарных методологий // Журнал Общества теории музыки. 2016. Вып. 3 (15). С. 18-29.

2. Бройтман С. Н. Теория литературы: В 2 т. / Под ред. Н. Д. Тамарченко. Т. 2: Бройтман С. Н. Историческая поэтика. М.: Академия, 2004.

3. Зырянов О. В. Эволюция жанрового сознания русской лирики: феноменологический аспект. Екатеринбург: Изд-во Урал. ун-та, 2003.

4. Проскурин О. А. Две модели литературной эволюции: Ю. Н. Тынянов и В. Э. Вацуро // Новое литературное обозрение. 2000. № 42. С. 63-77.

5. Kayser W. Geschichte der deutschen Ballade. Berlin: Junker und Dünnhaupt, 1936.

\section{References:}

1. Amrakhova, A.A. (2016) Theory of Genre in Russia in the Light of Today's Methods of Humanitarian Studies. Zhurnal Obshchestva teorii muzyki - The Journal of the Society for Theory of Music. 3(15). pp. 18-29. (In Russian).

2. Broytman, S.N. (2004) Teoriya literatury: $V 2 t$. [Literature Theory: In 2 Vols]. Vol. 2. Moscow: Akademiya.

3. Zyryanov, O.V. (2003) Evolyutsiya zhanrovogo soznaniya russkoy liriki: fenomenologicheskiy aspekt [The Evolution of the Genre Consciousness of Russian Lyrics: A Phenomenological Aspect]. Yekaterinburg: Ural State University.

4. Proskurin, O.A. (2000) Dve modeli literaturnoy evolyutsii: Yu. N. Tynyanov i V. E. Vatsuro [Two Models of Literary Evolution: Yu.N. Tynyanov and V.E. Vatsuro]. Novoe literaturnoe obozrenie - New Literary Observer. 42. pp. 63-77.

5. Kayser, W. (1936) Geschichte der deutschen Ballade. Berlin: Junker und Dünnhaupt.

\section{Полная библиографическая ссылка на статью:}

Бегичева, О. В. «Обертоны» романтической баллады в творчестве современных композиторов Кубани (на примере произведений Константина Пашкова) [Электронный ресурс] / О. В. Бегичева // Наследие веков. - 2019. - № 4. - С. 60-65. DOI: $10.36343 /$ SB.2019.20.4.007

\section{Full bibliographic reference to the article:}

Begicheva, O. V. (2019) The "Overtones" of the Romantic Ballad in the Works of Modern Composers of Kuban (On the Example of Works by Konstantin Pashkov). Nasledie vekov - Heritage of Centuries. 4. pp. 60-65. (In Russian). DOI: 10.36343/ SB.2019.20.4.007 